\title{
Conformational Changes of Whey and Pea Proteins upon Emulsification Approached by Front-Surface Fluorescence
}

\author{
Emma B. A. Hinderink, Claire C. Berton-Carabin,* Karin Schroën, Alain Riaublanc, \\ Bérénice Houinsou-Houssou, Adeline Boire, and Claude Genot
}

Cite This: J. Agric. Food Chem. 2021, 69, 6601-6612

Read Online

ACCESS

Llll Metrics \& More

Article Recommendations

Supporting Information

ABSTRACT: Proteins are widely used to stabilize emulsions, and plant proteins have raised increasing interest for this purpose. The interfacial and emulsifying properties of proteins depend largely on their molecular properties. We used fluorescence spectroscopy to characterize the conformation of food proteins from different biological origins (dairy or pea) and transformation processes (commercial or lab-made isolates) in solution and at the oil-water interface. The fourth derivative of fluorescence spectra provided insights in the local environment of tryptophan (Trp) residues and thus in the protein structure. In emulsions, whey proteins adsorbed with their Trp-rich region at the oil-water interface. Proteins in the commercial pea isolate were present as soluble aggregates, and no changes in the local environment of the Trp residues were detected upon emulsification, suggesting that these structures adsorb without conformational changes. The lab-purified pea proteins were less aggregated and a Trp-free region of the vicilin adsorbed at the oil-water interface.

KEYWORDS: oil-water interface, plant protein, tryptophanyl, right-angle fluorescence, UV-visible absorption

\section{INTRODUCTION}

Proteins are widely used to stabilize food oil-in-water $(\mathrm{O} / \mathrm{W})$ emulsions, i.e., dispersions of oil droplets in an aqueous phase. Dairy proteins (typically, whey or casein fractions) are excellent emulsifiers and widely used in the food industry. ${ }^{1,2}$ They adsorb at the oil-water interface and stabilize the droplets by steric and electrostatic repulsions. ${ }^{3}$ Furthermore, whey proteins undergo conformational changes after adsorption $^{4,5}$ and form a viscoelastic layer, ${ }^{6,7}$ which has been related to a high stability of emulsion droplets to coalescence. ${ }^{8}$

Over the past decades, plant proteins such as soy, lentil, and pea proteins have gained interest as more sustainable emulsifiers. $^{9-12}$ Pea proteins are particularly popular due to their ability to grow in Europe and to their low allergenic potential. ${ }^{13}$ During the production of commercial pea protein isolates, heat, solvents, and $\mathrm{pH}$-shifts are applied, which results in substantial chemical and structural changes of the proteins $^{14,15}$ and consequently to decreased protein solubility. The emulsifying properties of commercial pea proteins have already been studied, and it is clear that they suffer some drawbacks, such as limited emulsifying capacity due to their low solubility at food-relevant $\mathrm{pHs}^{16,17}$ Commercial pea proteins are able to form stiff interfacial layers at the oilwater interface; however, the layer is less interconnected compared to whey protein-stabilized interfacial layers. ${ }^{6,12}$ Therefore, the use of pea protein concentrates and isolates obtained from milder processes have recently gained interest. $^{18,19}$ The resulting lab-purified isolates contain nondenatured proteins which are less aggregated compared to commercial isolates but also contain more nonproteinaceous components such as polyphenols, carbohydrates, and lipids, due to the lower extent of purification achieved. ${ }^{20}$ It is therefore expected that their conformation and interfacial properties will differ from those of commercially obtained isolates.

Fluorescence spectroscopy is a classical method to characterize the structural conformation of proteins. ${ }^{21,22}$ An advantage of fluorescence spectroscopy is the lack of extrinsic probes and of complex sample preparation which may modify the protein structure (e.g., denaturation and new interactions). The method relies on the intrinsic fluorescence properties of the three aromatic amino acid residues in the protein: phenylalanyl, tyrosinyl, and tryptophanyl. Emission spectra of most proteins are typically dominated by the contribution of tryptophan (Trp) which emits at the longest wavelengths and has the largest extinction coefficient and the highest quantum yield. Furthermore, the excitation energy of tyrosine (Tyr) residues can be transferred to the Trp residues. An interesting property is the sensitivity of Trp fluorescence to its local environment. Consequently, changes in the Trp emission spectra can be related to changes in the tertiary protein structure, e.g., conformational changes, subunit association, substrate binding, or denaturation. ${ }^{22}$ In classical fluorescence spectroscopy, experiments are done in right-angle mode using dilute solutions with absorbances below 0.1. At absorbances higher than 0.1, the inner filter effect induces absorption of the exciting radiation or reabsorption of the emitted light. To

Received: February 17, 2021

Revised: April 11, 2021

Accepted: May 17, 2021

Published: June 4, 2021 
overcome this problem, front-surface fluorescence spectroscopy can be used to characterize turbid samples such as suspensions and emulsions. ${ }^{23-26}$ The shape of the spectra and maximum emission wavelength provide information regarding the overall location of the Trp residues. In addition, by calculating the fourth-derivative of the emission spectra, it is possible to distinguish the partitioning of Trp residues between hydrophobic and hydrophilic environments. ${ }^{24,25}$

Pea protein isolates are composed out of legumin, vicilin, and convicilin. Pea protein as most plant storage proteins are diverse in terms of primary structure. ${ }^{27}$ Based on the reviewed sequences found in the Uniprot database, legumin, convicilin, and vicilin are expected to contain $12-18,9-12$, and 0 Trp residue per protein chain, respectively; $42-78,42-45$, and 27 Tyr residue per protein chain; and 48-120, 30-60, and 33-66 Phe residue per protein chain. It is expected that these aromatic amino acids are relevant intrinsic probes for the pea protein conformation.

In this work, we aimed to investigate the conformational changes induced upon emulsification of proteins present in food ingredients arising from different biological origins and transformation processes: whey protein isolate, commercial pea protein isolate, and mildly purified pea proteins. We chose to tackle this question by deploying a comprehensive array of fluorescence spectroscopic characterisations.

We used UV-visible absorption and emission fluorescence spectroscopy to gain insight into the tertiary structure of the proteins. We focused on the fluorescence of Trp residues as affected by their environment, and we also took the contribution of the Tyr residues' fluorescence into account, which can give information about the energy transfer from Tyr to Trp and, thus, about interactions occurring within the peptide chain. In that respect, we compared in-house purified pea proteins with commercial pea proteins and chemically denatured commercial pea proteins (using $6 \mathrm{M}$ guanidine hydrochloride) to obtain insights in their quaternary and tertiary structure change as a result of processing. Furthermore, we studied the structural changes of the proteins when present at the oil-water interface in emulsions using front-surface fluorescence. The fourth derivative spectra were calculated to deconvolute the contribution of Trp residues present in hydrophilic and hydrophobic environments, making this work an original and important step to unravel the interfacial behavior and emulsifying properties of plant proteins.

\section{MATERIAL AND METHODS}

2.1. Materials. Sodium phosphate dibasic, sodium phosphate monobasic, sodium dodecyl sulfate (SDS), Tween 20, and guanidine hydrochloride were purchased from Sigma-Aldrich (Saint Louis, MO, U.S.A.) and were at least of analytical grade. A bicinchoninic acid kit including a standard bovine serum albumin (BSA) solution was purchased from Thermo Fisher Scientific (Massachusetts, U.S.A.). Mini protean gels (BOLT, Tris-Bis $4-12 \%$, precast polyacrylamide gels, 10-wells), NuPAGE MES SDS (running buffer), and SeeBlue Prestained standard (Novex) were used for SDS-PAGE analysis and purchased from Thermo Fischer Scientific. Instant Blue protein stain was purchased from Sigma aldrich. Sunflower oil was purchased from a local supermarket and stripped with alumina powder (MP Alumina N-Super I, MP Biomedicals, France) to remove surface-active impurities and tocopherols, as described previously. ${ }^{28}$ Ultrapure water was obtained from a Milli-Q Reference A+ system (Millipore Corporation, Billerica, Massachusetts, U.S.A.) and used for all of the experiments.

Whey protein isolate (WPI, BiPro, Davisco, Switzerland) and pea protein isolate (cPPI, NUTRALYS s85 F, Roquette, France) were used as commercial protein ingredients. To prepare the in-house extracted pea protein isolate (iePPI), pea seeds (Alimex Europe BV, Sint Kruis, The Netherlands) were milled (Hosokawa-Alpine, Augsburg, Germany) to obtain the yellow pea flour. The flour (average particle size of $100 \mu \mathrm{m}$ ) was first dispersed in distilled water $(1: 9 \mathrm{w} / \mathrm{w})$ at $4{ }^{\circ} \mathrm{C}$ for $2 \mathrm{~h}$. The $\mathrm{pH}$ was set and maintained at 8.0 by progressive addition of $0.5 \mathrm{M} \mathrm{NaOH}$ solution, using a $\mathrm{pH}$-stat, and maintained at this $\mathrm{pH}$. The suspension was then centrifuged at $17000 \mathrm{~g}$ for $20 \mathrm{~min}$ at $4{ }^{\circ} \mathrm{C}$. The supernatant was filtered using a filter paper (5951/2, Whatman). The $\mathrm{pH}$ of the filtered supernatant was lowered to 4.5 using $1 \mathrm{M} \mathrm{HCl}$, and stirred overnight at $4{ }^{\circ} \mathrm{C}$. The obtained mixture was centrifuged at $17000 \mathrm{~g}$ for $20 \mathrm{~min}$ at $4{ }^{\circ} \mathrm{C}$, and the pellet was resuspended in ultrapure water $(1: 9 \mathrm{w} / \mathrm{w})$ for $1 \mathrm{~h}$ at 20 ${ }^{\circ} \mathrm{C}$ before adjusting to $\mathrm{pH}$ 8.0. The mixture was stirred overnight at $\mathrm{pH}$ 8.0. The suspension was centrifuged at $17000 \mathrm{~g}$ for $20 \mathrm{~min}$ at $4{ }^{\circ} \mathrm{C}$, and the supernatant was collected and centrifuged again using the same conditions. The obtained protein solution (final supernatant) was dialyzed ( $5 \mathrm{kDa}$, Hydrosart, Sartorius) against ultrapure water until the conductivity of the external liquid did not decrease anymore $(38 \mu \mathrm{S} / \mathrm{cm})$. Subsequently, the dialyzed solution was freeze-dried and stored at $-20{ }^{\circ} \mathrm{C}$ until further use. The compositional analysis of the nonprotein material present in the pea protein samples (iePPI and cPPI) is reported by Kornet et al. ${ }^{20}$ Briefly, the carbohydrate content was 3.4 and 4.3 , the starch/starch derivative content 0.3 and 0.1 , and the ash content 6 and $1.5 \mathrm{~g} / 100 \mathrm{~g}$ d.m., for iePPI and cPPI, respectively. The legumin and vicilin/convicilin fractions were produced using a protocol previously established and described. ${ }^{29}$

The amino acid composition and protein content of WPI, cPPI (commercial), and iePPI (in-house extracted) were analyzed by Triskelion (Utrecht, The Netherlands) and are reported in Table 1. The amino acid composition was determined by a validated method based on ISO-13903:2005. Briefly, the samples were oxidized with performic acid, before overnight hydrolysis in $6 \mathrm{~mol} / \mathrm{L}$ hydrochloric acid. The hydrolyzed samples were separated by anion-exchange

Table 1. Amino Acid Composition in g/100 g Dry Matter (DM) of the WPI, iePPI, and cPPI Powders

\begin{tabular}{|c|c|c|c|}
\hline \multirow[b]{2}{*}{ amino acid $\mathrm{g} / 100 \mathrm{~g} \mathrm{DM}$} & \multicolumn{3}{|c|}{$\begin{array}{l}\text { amino acid residue }{ }^{a} \\
\text { content }\end{array}$} \\
\hline & WPI & iePPI & cPPI \\
\hline alanine & 3.8 & 2.6 & 2.5 \\
\hline arginine & 2.2 & 6.6 & 5.7 \\
\hline aspartic acid & 9.5 & 8.6 & 7.2 \\
\hline cysteine & 2.5 & 0.5 & 0.6 \\
\hline glutamic acid & 14.0 & 13.2 & 11.4 \\
\hline glycine & 1.1 & 2.4 & 2.2 \\
\hline histidine & 1.1 & 1.5 & 1.3 \\
\hline isoleucine & 4.7 & 3.5 & 3.0 \\
\hline leucine & 10.4 & 6.0 & 5.1 \\
\hline lysine & 8.3 & 5.6 & 4.6 \\
\hline methionine & 1.8 & 0.6 & 0.7 \\
\hline proline & 3.0 & 2.8 & 2.4 \\
\hline serine & 2.8 & 3.4 & 2.9 \\
\hline threonine & 3.7 & 2.3 & 2.2 \\
\hline valine & 4.1 & 3.5 & 3.2 \\
\hline tryptophan & 2.1 & 0.6 & 0.6 \\
\hline tyrosine & 3.0 & 2.6 & 2.2 \\
\hline phenylalanine & 2.8 & 3.9 & 3.5 \\
\hline total amino acid residues $(\mathrm{g} / 100 \mathrm{~g} \mathrm{DM})$ & 80.9 & 70.1 & 61.3 \\
\hline $\begin{array}{l}\text { nitrogen content in the amino acid residues } \\
(\mathrm{g} / 100 \mathrm{~g} \mathrm{DM})\end{array}$ & 12.8 & 12.6 & 10.9 \\
\hline total nitrogen content by Dumas (g/100 g DM) & 14.9 & 14.7 & 12.6 \\
\hline nitrogen-to-protein conversion factor & 6.31 & 5.58 & 5.60 \\
\hline
\end{tabular}

${ }^{a}$ Amino acid residue results from the removal of the $\mathrm{H}_{2} \mathrm{O}$ molecule upon formation of the polypeptide bond. 
chromatography and detected after postcolumn derivatization with ninhydrin by an L-8900 amino acid analyzer (Hitachi, Tokyo, Japan). Norvaline served as internal standard for quantification. Tryptophan was determined by a validated method based on ISO-13904:2005. With 5-methyltryptophane as the internal standard, samples were hydrolyzed in a saturated barium hydroxide solution under nitrogen in an autoclave. Tryptophan and the internal standard were determined by reversed-phase HPLC with fluorescence detection. The resulting amino acid compositions are in line with previously reported compositions of $\mathrm{WPI}^{30}$ and PPI. ${ }^{31}$ The water content was measured using the Karl Fischer method, and the total nitrogen content was measured using a Flash EA 1112 series Dumas analyzer (Interscience, Breda, The Netherlands).

2.2. Preparation of Aqueous Phases. WPI (1 wt \%) was dissolved in $10 \mathrm{mM}$ phosphate buffer $(\mathrm{pH} 7.0)$ and stirred overnight at $4{ }^{\circ} \mathrm{C}$. For the pea protein ingredients, cPPI (6 wt \%) and iePPI (2 wt \%) were dispersed in that same buffer and stirred for at least $48 \mathrm{~h}$ at $4{ }^{\circ} \mathrm{C}$; the insoluble part was removed by centrifugation $(12000 \mathrm{~g}$, $40 \mathrm{~min}$ ) and the supernatant was collected and centrifuged again under the same conditions to ensure complete removal of the insoluble fraction. The second supernatant was collected, and its protein content was determined with the BCA assay ${ }^{32}$ at $562 \mathrm{~nm}$ using a UV-visible spectrophotometer (lambda, 12, PerkinElmer, Norwalk, U.S.A.), leading to $25 \%$ and $60 \%$ of the total proteins present in the starting dispersion for cPPI and iePPI, respectively. For front-surface fluorescence experiments, the solutions were diluted to 1 wt $\%$ protein using the same phosphate buffer, and for right-angle fluorescence measurements, they were diluted to 0.1 and $0.025 \mathrm{wt} \%$ for iePPI and cPPI, respectively. Furthermore, an 8 wt \% cPPI dispersion was prepared in the same phosphate buffer and stirred for at least $48 \mathrm{~h}$ at $4{ }^{\circ} \mathrm{C}$; the insoluble part was removed by centrifugation $(12000 \mathrm{~g}, 40 \mathrm{~min})$. Guanidine hydrochloride salt was added to the supernatant (concentrated cPPI-solution), to reach a concentration of $6 \mathrm{M}$, forming a cPPI solution in $6 \mathrm{M}$ guanidine hydrochloride referred to as cPPI*. Guanidine hydrochloride is a chaotropic agent that chemically denatures the protein by binding to the hydrophobic patches, resulting in a loss of the tertiary structure and exposure of the amino acids initially buried in the protein core. ${ }^{33}$ The soluble protein content was measured, and the $\mathrm{CPPI}^{*}$ solution was further diluted with $6 \mathrm{M}$ guanidine hydrochloride in $10 \mathrm{mM}$ phosphate buffer to reach 0.1 or $1 \mathrm{wt} \%$ protein. The WPI was directly dispersed (1 wt \%) in the $6 \mathrm{M}$ guanidine hydrochloride buffer, stirred overnight at $4{ }^{\circ} \mathrm{C}$ and subsequently diluted to $0.1 \mathrm{wt} \%$ protein using the same buffer.

The size of protein structures was measured with dynamic light scattering (DLS) using a Zetasizer Nano Series (Nano-Zs, Malvern Instruments, Germany). The samples were diluted to $1 \mathrm{~g} / \mathrm{L}$ and filtered $(0.2 \mu \mathrm{m}$, Minisart High-Flow, Sartorius Stedim Biotech $\mathrm{GmbH}$, Goettingen, Germany). The measurements were performed in manual mode; 10 runs of $60 \mathrm{~s}$ were collected and repeated three times for each measurement $\left(20{ }^{\circ} \mathrm{C}\right)$. The correlation functions are reported in the Supporting Information, Figure S1.

2.3. Preparation and Characterization of Emulsions. Coarse emulsions were prepared by mixing $10 \mathrm{wt} \%$ stripped sunflower oil with each of the protein solutions (1 wt \%) using a high-speed blender (Heidolph Silent Crusher, Schwabach, Germany) at 20000 $\mathrm{rpm}$ for $30 \mathrm{~s}$. The coarse emulsion was passed through a high pressure homogenizer (Panda plus 1000; GEA Niro Saovi, Italy) at 200 bar for $3 \mathrm{~min}$.

The droplet size distribution was measured by static light scattering using a Horiba LA-960 laser particle size analyzer (Horiba Scientific, Jobin Yvon, France). The refractive indices were set at 1.465 and 1.330 for the dispersed and continuous phases, respectively. Emulsions were diluted in 1 wt \% SDS solution prior to the measurement or, in the case of the cPPI*-stabilized emulsions, in $1 \mathrm{wt}$ $\%$ Tween 20 solution, to disrupt possible droplet flocs and measure the individual droplet sizes.

Fresh emulsions were centrifuged at $15000 \mathrm{~g}$ for $1 \mathrm{~h}$ to separate the cream phase from the serum. The serum phase was collected by cautiously making a hole at the bottom of the tube and filtered with a $0.2 \mu \mathrm{m}$ filter (Minisart High-Flow, Sartorius Stedim Biotech GmbH,
Goettingen, Germany). The soluble protein content was determined with the BCA assay. The surface load was calculated with eq 1.

$$
\Gamma=\frac{C_{s} d_{3,2}}{6 \phi}
$$

where $C_{s}$ is the adsorbed protein concentration calculated by subtracting the protein concentration in the serum phase from the initial protein concentration of the solution used for emulsion preparation, $d_{3,2}$ is the surface weighted mean droplet diameter of the emulsion (diluted in $1 \mathrm{wt} \%$ SDS or $1 \mathrm{wt} \%$ Tween-20), and $\phi$ is the dispersed phase volume fraction.

The creamed phase (iePPI, cPPI, and WPI) obtained after centrifugation was redispersed into 1 wt \% SDS and then recentrifuged. The supernatant, containing the initially adsorbed proteins, was collected and analyzed together with the starting solution and serum phase by SDS-PAGE under reducing conditions. The samples were mixed $(1: 1 \mathrm{v} / \mathrm{v})$ with a $\mathrm{pH} 6.8$ buffer containing Tris-HCl $0.5 \mathrm{M}$, glycerol $30 \% \mathrm{w} / \mathrm{v}$, SDS $10 \% \mathrm{w} / \mathrm{v}$, bromophenol blue $0.5 \% \mathrm{w} / \mathrm{v}$ and 2 -mercaptoethanol, vortexed and heated at $95{ }^{\circ} \mathrm{C}$ for 5 min in a heating block. Five microliters protein standard (SeeBlue Prestained, Novex, LC5625, Mw 3-109 kDa) and $20 \mu \mathrm{L}$ of the diluted samples in sample buffer were loaded on the gel. A MES running buffer of $\mathrm{pH} 7.3$ was used. Electrophoresis was performed in a Mini Gel Tank (ThermoFischer Scientific, U.S.A.) at $150 \mathrm{~V}$ for 45 $\mathrm{min}$. After electrophoresis the gels were stained with Instant Blue for 1 h. Subsequently, the gels were washed with ultrapure water for $12 \mathrm{~h}$ before analysis. Gels were scanned and analyzed using a calibrated densitometer (ImageScanner III LabScan 6.0 (GE Healthcare, U.S.A.)) and Image Lab software (Bio-Rad laboratories, U.S.A.). The molecular weights were determined by point to point regression. For WPI solutions, mainly bovine serum albumin (BSA), $\beta$ lactoglobulin $(\beta$-lg), $\alpha$-lactalbumin $(\alpha$-lac), and traces of immunoglobulins were found. PPI containing samples mainly consisted of convicilin $(\sim 71 \mathrm{kDa})$, vicilin subunits $(\sim 30, \sim 34, \sim 47$ and $\sim 50 \mathrm{kDa})$, $\alpha$-legumin $(38-40 \mathrm{kDa}), \beta$-legumin $(19-22 \mathrm{kDa}),{ }^{34}$ and vicilin fragments $\left(\sim 12.5-19^{35}\right)$. The pea proteins dissociated in the buffer containing SDS solution and 2-mercaptoethanol, leading to multiple bands in SDS-PAGE. The sum of the subunits is reported for the different pea proteins.

2.4. Absorption Spectra. Absorption spectra of protein solutions were recorded with a UV-visible spectrophotometer (Shimadzu UV1800, Shimadzu corporation, Kyoto, Japan) coupled with the UV probe software (v2.30). UV-visible spectra were recorded for solutions at $1 \mathrm{~g} / \mathrm{L}$ for WPI and iePPI and at $0.25 \mathrm{~g} / \mathrm{L}$ for cPPI, to have absorbances of $\sim 1$ at $280 \mathrm{~nm}$. The spectra were acquired between 200 and $650 \mathrm{~nm}$ with a scan speed of $360 \mathrm{~nm} / \mathrm{min}$ and a sampling interval of $0.5 \mathrm{~nm}$. Ultrapure water was used for setting the baseline.

The theoretical UV-visible absorbance spectra of each protein dispersion were calculated for $1 \mathrm{~g} / \mathrm{L}$ of protein. Experimental reference spectra of Trp, Tyr, and Phe were obtained from the PhotochemCAD database. ${ }^{36,37}$ The theoretical spectra were calculated as a linear combination of each reference spectrum based on the respective content of Trp, Tyr, and Phe of the protein isolate.

2.5. Fluorescence Measurements. Emission spectra were recorded using a double-monochromator single-photon counting spectrofluorimeter (FLSP920, Edinburgh Instruments, UK) equipped with a $450 \mathrm{~W}$ xenon lamp (Xe900) as the light source and either a front-surface (FF) accessory (concentrated solutions, emulsions, and creams) or a classical temperature-controlled right-angle (RA) accessory (diluted solutions). The spectra were automatically corrected in excitation and emission from instrument distortions. Figure 1 shows a schematic overview of the experimental design applied. In the RA-configuration, the temperature was controlled and set at $20{ }^{\circ} \mathrm{C}$. For FF measurements, the temperature of the room was controlled (set at $20^{\circ} \mathrm{C}$ ) and, in practice, varied between 18 and 20 ${ }^{\circ} \mathrm{C}$.

RA fluorescence emission spectra were recorded for diluted protein solutions. The protein solutions were diluted such that the total 


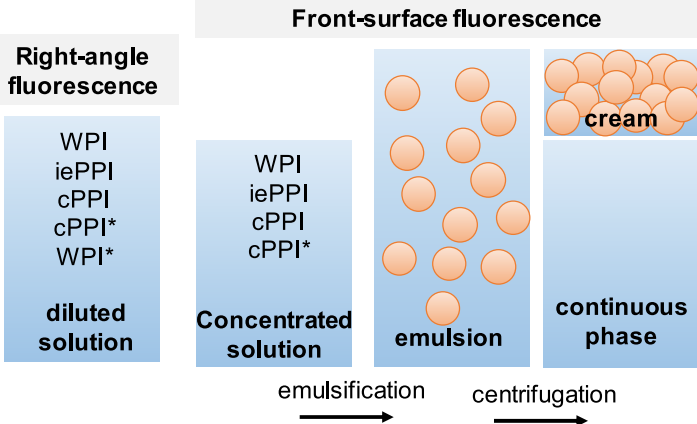

Figure 1. Schematic overview of the samples on which right-angle or front-surface fluorescence measurements were performed. For the right-angle fluorescence measurements, the solutions were diluted in order to have absorbances $\sim 0.1$ at $280 \mathrm{~nm}$.

absorbance at $280 \mathrm{~nm}$ was $\sim 0.1$ (as determined using the abovedescribed UV-visible spectrophotometer) to minimize the inner filter effect. WPI and iePPI solutions were accordingly used at $0.1 \mathrm{~g} / \mathrm{L}$, and cPPI and $\mathrm{cPPI}^{*}$ solutions at $0.025 \mathrm{~g} / \mathrm{L}$. The diluted samples were placed in a $10 \times 4 \mathrm{~mm}$ reduced pathway quartz cell. RA-fluorescence emission spectra were recorded from 260,275 , or 290 to $450 \mathrm{~nm}$ (step $1 \mathrm{~nm}$, dwell time $=0.3 \mathrm{~s}$ ) with excitation wavelengths set at 260 , 275 , or $290 \mathrm{~nm}$, respectively. The slit widths were set at 4 and $2 \mathrm{~nm}$ for excitation and emission pathways, respectively. The background intensities of the buffer solutions (10 $\mathrm{mM}$ phosphate buffer, or $6 \mathrm{M}$ guanidine hydrochloride) were subtracted from the protein emission spectra. To compare the shapes of the emission spectra among the different samples, all measured emission intensities were normalized (divided by the maximum absorbance of the sample). The fluorescence spectra recorded with excitation wavelengths of 275 and $290 \mathrm{~nm}$ were normalized at the signal at $365 \mathrm{~nm}$, where only Trp emits. The difference between both normalized spectra represents the Tyr contribution to the spectrum with an excitation wavelength of $275 \mathrm{~nm}^{21}$

Fluorescence emission spectra of emulsions, creamed phases, serum phases, and 1 wt \% starting solutions were recorded in FF mode. Before analysis, the serum phases were filtered through a $0.2 \mu \mathrm{m}$ filter, and the creamed phases were gently placed on filter paper to remove loosely bound water. Samples were measured in a $0.5 \mathrm{~mm}$ pathway quartz cell. FF fluorescence emission spectra were recorded from 275 or 290 to $450 \mathrm{~nm}$ (step $0.5 \mathrm{~nm}$, dwell time $=0.3 \mathrm{~s}$ ) with excitation wavelengths set at 275 or $290 \mathrm{~nm}$, respectively. The slit widths were set at $2 \mathrm{~nm}$ in both excitation and emission pathways. FF emission spectra were normalized to a maximum intensity of 1 , and the normalized spectra were used for fourth-derivative calculations. The spectra were smoothed by the Savitsky-Golay procedure (polynomic order 2, width 21 points), and fourth derivatives were calculated according to the Savitzky-Golay procedure (width 40 points). The data sets were analyzed with Unscrambler x10.2 (CAMO Software, Oslo, Norway).

2.6. Statistical Analysis. Each measurement was performed in at least independent duplicates. Two independently prepared emulsions were used for the FF measurements and surface load determination. IBM SPSS statistics software was used for statistical analysis with oneway ANOVA and to compare means posthoc with the Tukey method. Significance was established with $p<0.05$.

\section{RESULTS AND DISCUSSION}

3.1. Absorption Spectra. The absorption spectra measured for WPI, iePPI and cPPI solutions are reported in Figure 2. The theoretical spectra were calculated using the amino acid composition of the protein powders (Table 1), assuming that the extinction coefficients and the absorption spectra of the residues in the proteins are similar to those of the free aromatic amino acids (Figure 2, insert).

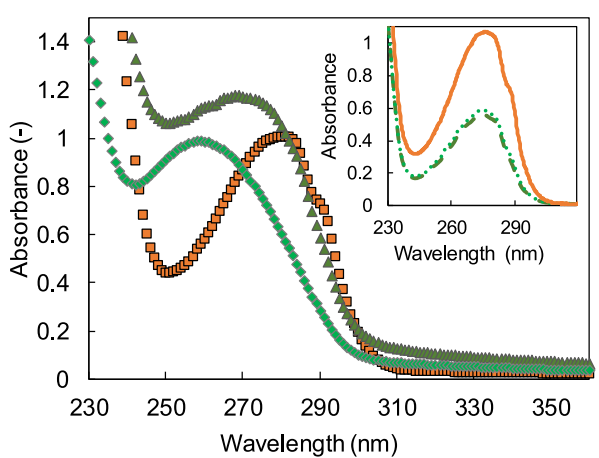

Figure 2. Absorption spectra of $1 \mathrm{~g} / \mathrm{L}$ WPI (orange square), $1 \mathrm{~g} / \mathrm{L}$ iePPI (black triangle), and $0.25 \mathrm{~g} / \mathrm{L}$ cPPI (green diamond) solutions in $10 \mathrm{mM}$ phosphate buffer, $\mathrm{pH}$ 7.0. The inset shows the theoretical spectra of $1 \mathrm{~g} / \mathrm{L}$ WPI (orange line), iePPI (black line), and cPPI (green line) as calculated from their amino acid composition (Table $1)$.

The wavelength of maximum absorbance in the absorption spectrum of the WPI solution was $280 \mathrm{~nm}$, which is typical for proteins. ${ }^{38}$ At $289 \mathrm{~nm}$, a shoulder was present in the spectrum, which is characteristic for the absorption of Trp residues. Shoulders between 250 and $270 \mathrm{~nm}$ characterize Phe adsorption. ${ }^{21}$ No apparent contribution of the Phe residues to the spectra was observed due to the low molecular concentration in the sample $(17.0 \mu \mathrm{M}$, Supporting Information, Table S1) and the low extinction coefficient of Phe $(\varepsilon=$ $191 \mathrm{~cm}^{-1} \mathrm{M}^{-1}$ at $257 \mathrm{~nm}$ ). The similar shape of the theoretical absorbance spectrum (Figure 2) confirms that the aromatic amino acids are solely responsible for the absorption spectrum of the WPI solution.

For the iePPI solution, the maximum absorbance was at 270 $\mathrm{nm}$, which is thus shorter than typical maxima for Trp (280 $\mathrm{nm})$ and Tyr $(275.5 \mathrm{~nm})$ residues. The shoulders between 250 and $270 \mathrm{~nm}$ correspond to the absorption of Phe residues. The occurrence of these peaks confirms the high molar concentration in Phe residues $(27.0 \mu \mathrm{M})$ compared to $\operatorname{Trp}$ and Tyr residues (3.1 and $26.6 \mu \mathrm{M}$, respectively; Supporting Information, Table S1). The nonzero absorption above 320 $\mathrm{nm}$ can be attributed to the turbidity of the sample due to the presence of nonprotein compounds and/or protein aggregates. ${ }^{39}$ At neutral $\mathrm{pH}$ and low ionic strength $(<0.1 \mathrm{M})$, legumin protein aggregates into supramolecular protein structures, ${ }^{40}$ therewith contributing to the turbidity of the sample. The theoretical iePPI absorbance spectrum has a maximum absorbance at $275 \mathrm{~nm}$, with a lower total absorbance compared to the experimental spectra. The blue-shifted maximum wavelength and the higher total absorbance of the experimental spectrum suggests the presence of other, nonprotein absorbing species (e.g., polyphenols).

The absorbance spectrum for the cPPI solution was recorded at a protein concentration of $0.25 \mathrm{~g} / \mathrm{L}$ due to the high absorption of the sample. The maximum absorbance was at $258 \mathrm{~nm}$, which is a shorter wavelength than as found for the iePPI solution $(275 \mathrm{~nm})$ and of proteins in general $(280 \mathrm{~nm})$. Commercial plant protein isolation processes involve heat, $\mathrm{pH}$ changes, and different solvents. ${ }^{41}$ As a result, proteins are oxidized, ${ }^{15}$ denatured (no endothermic peak in DSC measurements) and highly aggregated. ${ }^{18}$ The protein hydrodynamic radius was measured using dynamic light scattering (DLS). Due to the large polydispersity of the pea protein solutions, as a result of the broad range of aggregated structures, the 

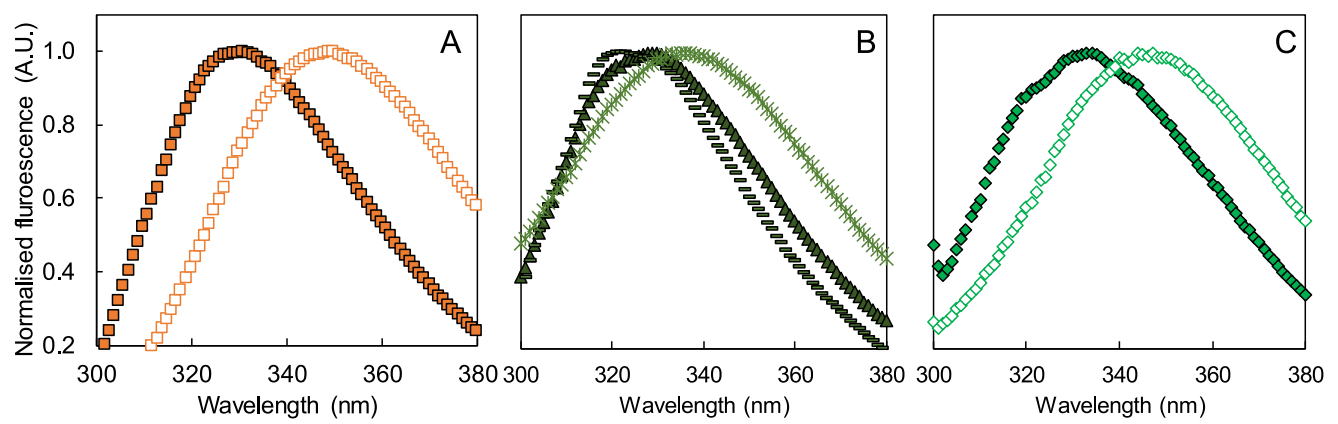

Figure 3. Emission spectra (recorded at $\lambda_{\text {ex }}=290 \mathrm{~nm}$ ) normalized at their maximum intensity (A) $1 \mathrm{~g} / \mathrm{L}$ WPI (solid orange square), $1 \mathrm{~g} / \mathrm{L}$ WPI* (open orange square), (B) $1 \mathrm{~g} / \mathrm{L}$ iePPI (black triangle), vicilin and convicilin (*), legumin (-), and (C) $0.25 \mathrm{~g} / \mathrm{L} \mathrm{cPPI}$ (solid green diamond), 0.25 $\mathrm{g} / \mathrm{L}$ cPPI* (open green diamond) solutions. Detailed information about $\lambda_{\max }$ and bandwidths are reported in the Supporting Information, Table S2.

method is not appropriate to determine the individual protein radii in such samples. However, the correlation function (correlation coefficient as a function of the delay time) gives insight into the difference between the overall protein sizes. A shift of the correlation curve to longer delay times for cPPI compared to iePPI and native protein samples (vicilin/ convicilin and legumin fraction) was observed (Supporting Information, Figure S1). These results confirm that larger structures (e.g., aggregates) were present in the cPPI solution. It should be noted that such a process-induced aggregation is more extensive than the aggregation related to the quaternary structure of native legumin at low ionic strength and neutral $\mathrm{pH}$. The theoretical spectrum (at $1 \mathrm{~g} / \mathrm{L}$, Figure $2 \mathrm{~B}$ ) has a maximum wavelength at $275 \mathrm{~nm}$ and a lower total adsorption compared to the experimental spectra. This suggests that the experimental spectrum was largely modified by nonprotein compounds and aggregates resulting from the process applied to produce the ingredient.

3.2. Right-Angle Fluorescence Emission Spectra. In right-angle fluorescence spectroscopy, the total absorbance of the sample should not exceed 0.1 (at $\sim 280 \mathrm{~nm}$ ) to avoid as much as possible the inner filter effect. Without the inner filter effect, the emission intensities reflect the actual emission properties of the fluorophores. To comply with this requirement, the iePPI- and WPI solutions were diluted to a final protein concentration of $0.1 \mathrm{~g} / \mathrm{L}$ and the cPPI-solution to $0.025 \mathrm{~g} / \mathrm{L}$.

The complexity of the interpretation of protein fluorescence results from the presence of multiple fluorophores, including primarily the three aromatic amino acids-Phe, Tyr, and Trp-whose location may be distributed between different local environments. Yet, Trp largely dominates the fluorescence signal in Trp-containing proteins, and is the only amino acid with a high sensitivity to its local environment. ${ }^{22}$ Furthermore, at excitation wavelengths above $290 \mathrm{~nm}$, Trp is the only emitting amino acid. Therefore, a blue- or red-shift of the emission spectra recorded at $\lambda_{\text {ex }}>290 \mathrm{~nm}$ can be interpreted as a more hydrophilic or hydrophobic local environment of Trp residues, respectively, and is assumed to be a result of conformational changes, subunit association, substrate binding or denaturation. ${ }^{22}$ The spectral bandwidth (i.e., the width of the spectrum at half-maximum intensity $\left.\left(I_{\max } / 2\right)\right)$, gives an impression of how broadly Trp residues are distributed over different environments (e.g., $62 \mathrm{~nm}$ for of $\mathrm{N}$ acetyl-L-tryptophan amide at $\lambda_{\mathrm{ex}}=290 \mathrm{~nm}$, Supporting Information, Figure S2).

For the WPI solution, the maximum emission wavelength $\left(\lambda_{\max }\right)$ was at $331 \mathrm{~nm}$ (Figure 3$)$ and the spectral bandwidth 53 $\mathrm{nm}$ (Supporting Information, Table S2). The $\lambda_{\max }$ corresponds to Trp residues that are not directly accessible to water molecules, ${ }^{42,43}$ which is in line with previous data reported for WPI $\left(\lambda_{\max }=333, \mathrm{pH} \mathrm{7.1^{44 }}\right)$ and for pure $\beta$-lactoglobulin representing $\sim 70 \%$ of the protein in WPI $\left(\lambda_{\max }=332\right.$, $\mathrm{pH} 6-$ $8) .{ }^{43}$ After denaturing whey proteins in $6 \mathrm{M}$ guanidine hydrochloride (sample referred to as WPI*), a red shift $(9 \mathrm{~nm})$ of $\lambda_{\max }$ was observed, indicating that the local environment of Trp became more hydrophilic $(340 \mathrm{~nm})$. According to the classification of Burstein, this corresponds to Trp molecules in contact with bound water at the surface of the protein molecule. ${ }^{43}$ The $\lambda_{\max }$ recorded for WPI* $(340 \mathrm{~nm})$ was shorter compared to that of $N$-acetyl-L-tryptophan amide $\left(\lambda_{\max }=353\right.$ $\mathrm{nm})$, which could indicate that the proteins did not denature fully.

For the iePPI solution, $\lambda_{\max }$ was at $328 \mathrm{~nm}$ with a spectral bandwidth of $59 \mathrm{~nm}$. This suggests that the Trp residues are distributed between more contrasted local environments compared to WPI and in an overall more hydrophobic environment. Pea protein isolates are composed of two major protein fractions, legumin and vicilin/convicillin in a mass ratio of $1: 2$ (as determined by SDS-PAGE densitometry). At $\mathrm{pH} 7.0$ the legumin is a hexamer with a molecular weight of $360 \mathrm{kDa}$ and vicilin and convicilin a trimer with a molecular weight of $170 \mathrm{kDa}$ and $210-290 \mathrm{kDa}$, respectively. ${ }^{45,46}$ Since the proteins coexist in the iePPI solution, we recorded the emission spectra of native legumin and vicilin/convicilin fractions for comparison purposes (Figure 3C). The legumin had a $\lambda_{\max }$ at $321 \mathrm{~nm}$ and the vicilin and convicilin solution at $336 \mathrm{~nm}$, suggesting that the Trp residues are in a more hydrophilic environment in the legumin solution. However, the spectral bandwidth recorded for the vicilin and convicilin $(74 \mathrm{~nm})$ was much broader compared to the legumin solution $(52 \mathrm{~nm})$, which indicates a broader range of local environments of the Trp residues in the vicilin and convicilin solution.

The cPPI solution showed a $\lambda_{\max }$ at $334 \mathrm{~nm}$ with a shoulder at $321 \mathrm{~nm}$, which is probably a result of the wide distribution of local environments of the Trp residues in the protein, as also indicated by the broad bandwidth $(70.5 \mathrm{~nm})$. It is probably not vicilin and convicilin $\left(\lambda_{\max }=321 \mathrm{~nm}\right)$, since no native proteins remain in the commercial isolate, as suggested by the loss of the denaturation peak in DSC profiles of such samples, ${ }^{18}$ and the aggregated state of the sample (Figures 2, S1 in the Supporting Information). The $\lambda_{\max }$ is red-shifted after denaturation with guanidine hydrochloride to $344 \mathrm{~nm}$. The fact that the $\lambda_{\max }$ of the cPPI* is further red-shifted compared to $\mathrm{WPI}^{*}(340 \mathrm{~nm})$ suggests extensive protein unfolding or lower interactions of the peptide backbone of the protein with 
the Trp residues and higher exposure of the latter to free/ unbound water molecules.

Overall, the emission spectrum for WPI in phosphate buffer had the smallest bandwidth $(53 \mathrm{~nm})$, which represents the smallest spread of Trp residues between different local environments, followed by iePPI $(59 \mathrm{~nm})$ and cPPI $(70.5$ $\mathrm{nm})$. The shortest $\lambda_{\max }$ recorded for the iePPI solution indicates that this is the sample in which Trp residues were least able to interact with water molecules, and therefore, the most buried with the protein structure's core. ${ }^{47}$

To compare the Trp fluorescence emission intensity (i.e., the quantum yield) of the protein solutions, the emission spectra $\left(\lambda_{\mathrm{ex}}=290 \mathrm{~nm}\right)$ were normalized based on their Trp content (Figure 4 ). The tryptophan quantum yields of proteins

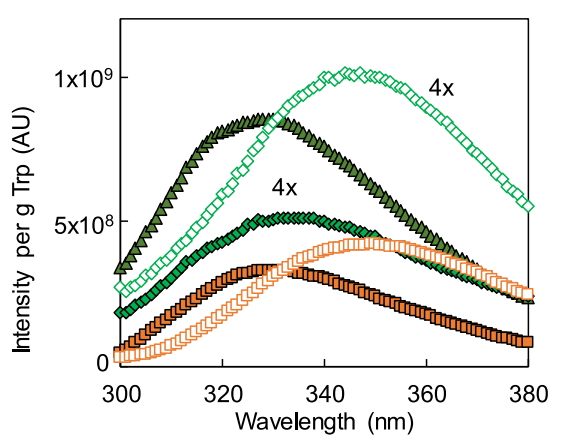

Figure 4. Maximum emission intensity per gram of tryptophan for WPI (solid orange square), WPI* (open orange square), iePPI (black triangle), $\mathrm{cPPI} 4 \mathrm{x}$ (solid green diamond), and CPPI* $4 \mathrm{x}$ (open green diamond) solutions (recorded at $\lambda_{\mathrm{ex}}=290 \mathrm{~nm}$ ). Detailed information about $\lambda_{\max }$ bandwidth, and emission intensity are reported in the Supporting Information, Table S2.

is variable due to the presence of other amino acids that may act as quencher, such as lysine and histidine, and of the amide groups in the peptide backbone. ${ }^{22,48}$ The fluorescence intensities of $\mathrm{CPPI}^{*}$ and $\mathrm{WPI}^{*}$ solutions were higher compared to those of the cPPI and WPI solutions, which can be related to the loss of tertiary protein structure and the subsequent decreased quenching. The iePPI solution showed a higher fluorescence intensity compared to the cPPI-solution, whereas both protein ingredients differ only slightly in their amino acid composition (Tables 1 and S1 in the Supporting Information). The absorption spectra (Figure 2) were indicative of the presence of nonprotein absorbing species in the cPPI sample and, e.g., interaction of the aromatic ring of flavonoids or phenolic acids with the aromatic residues may be responsible for quenching of the system. ${ }^{49}$ Besides, due to the extensive aggregated state of the proteins the Trp residues may be more quenched, due to the close proximity of other residues and functional groups, compared to the iePPI-solution. Finally, protein oxidation may have occurred during the cPPI isolation, which could lead to Trp degradation and thus decrease of the fluorescence signal. ${ }^{50,51}$

The WPI sample showed the lowest fluorescence intensity per mass of $\operatorname{Trp}$ (Figure 4). $\beta$-Lactoglobulin, the main protein in WPI, contains 2 Trp residues; the first one, $\operatorname{Trp} 19$, is buried within the hydrophobic binding pocket of the protein and displays fluorescence. The second, $\operatorname{Trp} 61$, is present at the surface of the protein, in the vicinity of a disulfide bond (Cys66-Cys160), a strong quencher ${ }^{52,53}$ that is not reduced by guanidine hydrochloride, and therefore, the quenching effect is probably still applied in the WPI* samples, at least to some extent.

We recorded fluorescence emission spectra at excitation wavelengths $\left(\lambda_{\mathrm{ex}}\right)$ of 275 and $290 \mathrm{~nm}$. At $\lambda_{\text {ex }}$ of $275 \mathrm{~nm}$, both Tyr and Trp residues emit, whereas at $\lambda_{\text {ex }}$ of $290 \mathrm{~nm}$, only Trp residues do so. To determine the Tyr contribution to the emission spectra, spectra recorded at $\lambda_{\text {ex }}=275$ and $290 \mathrm{~nm}$ were normalized by their emission intensity at $365 \mathrm{~nm}$ (where only Trp residues emit, Supporting Information, Figure S2). The difference between both spectra is the Tyr contribution to the total fluorescence recorded at $\lambda_{\mathrm{ex}}=275 \mathrm{~nm}$ (Figure 5).

In the difference spectra (Figure 5, black markers) of the pea protein samples (iePPI, cPPI, and cPPI*), $\lambda_{\max }$ was at $305 \mathrm{~nm}$, which is close to the value determined for $N$-acetyl-L-tyrosine
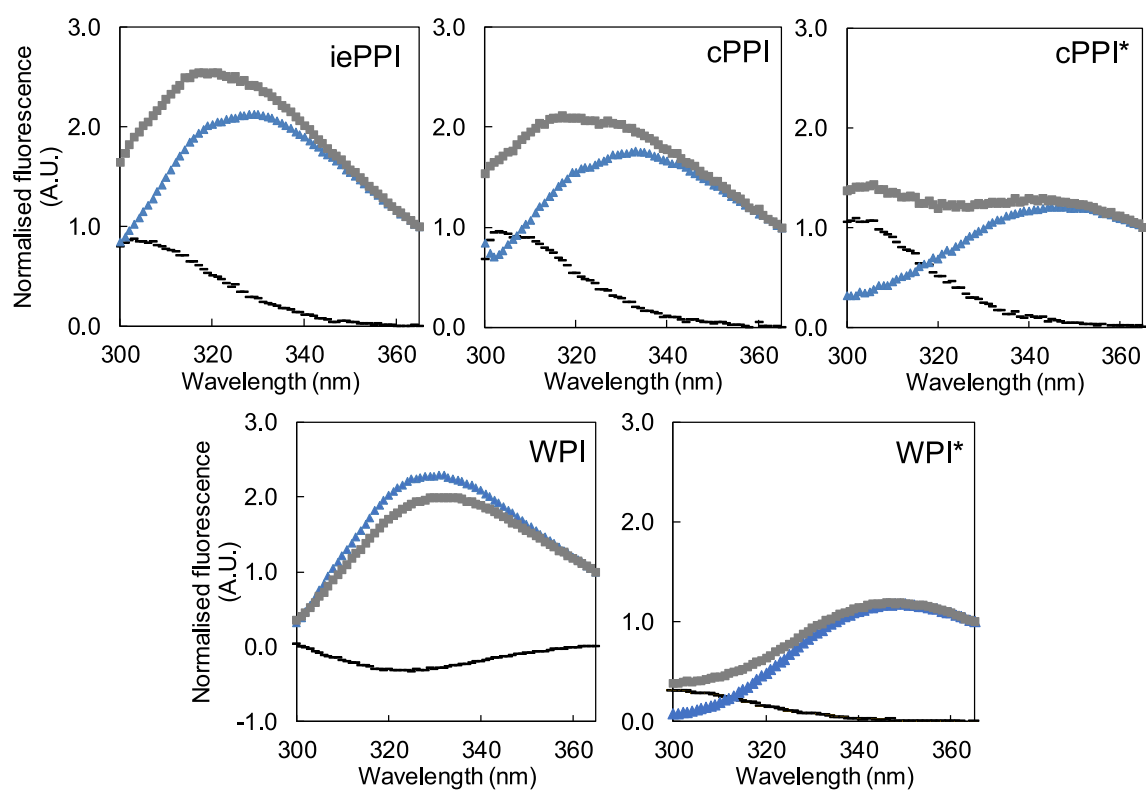

Figure 5. Emission spectra normalized at $365 \mathrm{~nm}$, for spectra recorded at $\lambda_{\mathrm{ex}}=290$ (solid blue triangle) or $275 \mathrm{~nm}$ (solid gray square) and the difference spectrum, i.e., normalized spectrum $\left[\lambda_{\mathrm{ex}}=275 \mathrm{~nm}\right]-$ normalized spectrum $\left[\lambda_{\mathrm{ex}}=290 \mathrm{~nm}\right](-)$. 

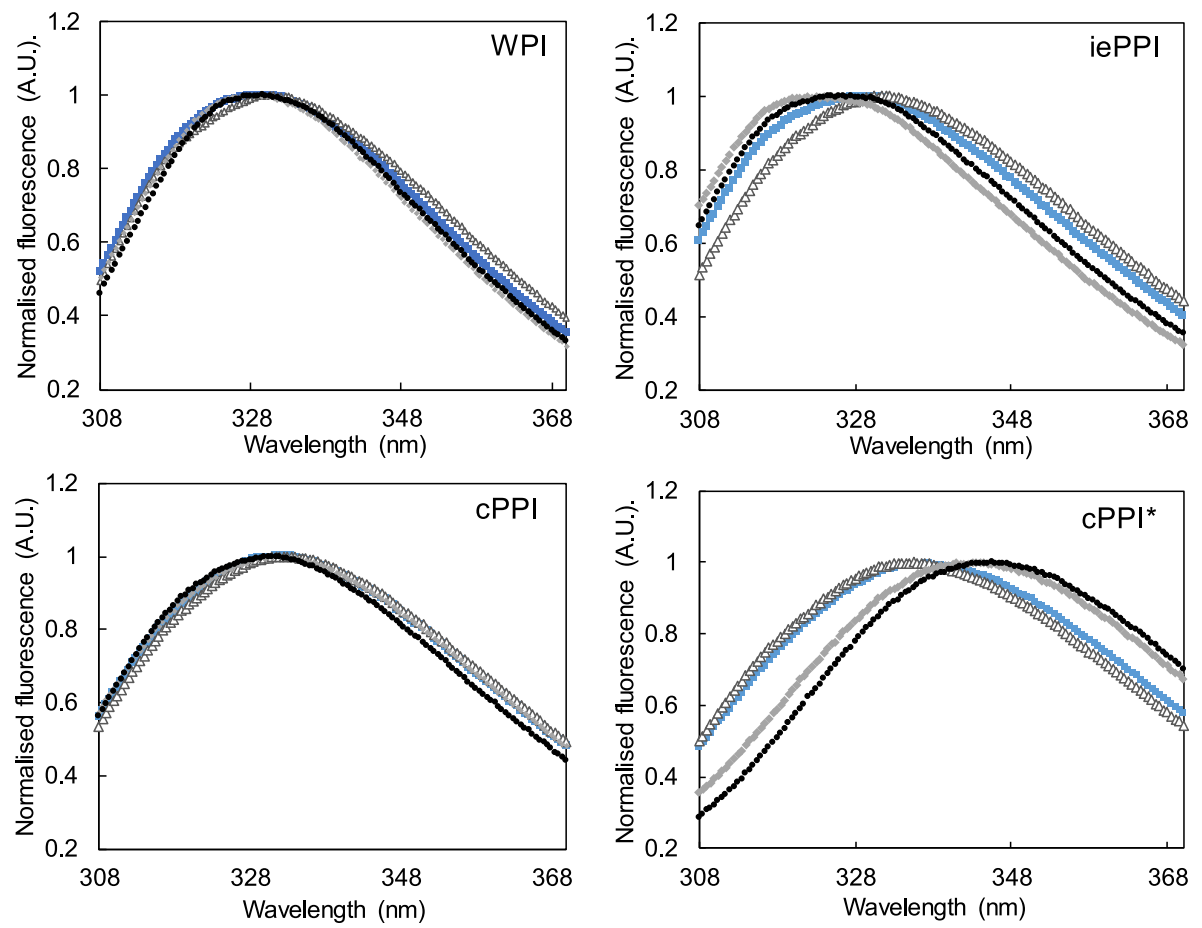

Figure 6. Normalized fluorescence emission spectra of emulsion (solid blue square), creamed (gray triangle), and serum (solid gray diamond) phases and initial solutions (solid black sphere) of WPI, iePPI, cPPI, or cPPI* (i.e., cPPI in $6 \mathrm{M}$ guanidine) containing samples recorded at $\lambda_{\mathrm{ex}}=$ $290 \mathrm{~nm}$. For clarity, only one representative spectrum is shown per sample, but similar trends were obtained for dependent and independent replicates.

Table 2. Maximum Emission Wavelength $\left(\lambda_{\max }\right)$ and Bandwidth of the Spectra Recorded with an Excitation Wavelength $\left(\lambda_{\mathrm{ex}}\right)$ of $290 \mathrm{~nm}^{a}$

\begin{tabular}{|c|c|c|c|c|c|c|c|c|}
\hline \multirow[b]{2}{*}{ initial fluorescence spectra } & \multicolumn{4}{|c|}{$\lambda \max ^{290}(\mathrm{~nm})$} & \multicolumn{4}{|c|}{ bandwidth $^{290}(\mathrm{~nm})$} \\
\hline & WPI & iePPI & cPPI & cPPI* & WPI & iePPI & cPPI & cPPI* \\
\hline emulsion & $329.5^{\mathrm{cd}}$ & $329.0^{c}$ & $332.0^{\mathrm{efg}}$ & $337.0^{\mathrm{i}}$ & $53.5^{\mathrm{B}}$ & $58.5^{\mathrm{E}}$ & $62.5^{\mathrm{G}}$ & $65.5^{\mathrm{J}}$ \\
\hline cream & $330.5^{\mathrm{de}}$ & $332.0^{\mathrm{fg}}$ & $332.5^{\mathrm{g}}$ & $334.0^{\mathrm{h}}$ & $55.5^{\mathrm{C}}$ & $59.0^{\mathrm{E}}$ & $62.5^{\mathrm{G}}$ & $64.5^{\mathrm{HI}}$ \\
\hline serum & $328.5^{\mathrm{c}}$ & $323.5^{\mathrm{a}}$ & $332.0^{\mathrm{fg}}$ & $343.5^{\mathrm{j}}$ & $51.0^{\mathrm{A}}$ & $55.0^{\mathrm{C}}$ & $63.0^{\mathrm{G}}$ & $65.5^{\mathrm{IJ}}$ \\
\hline solution & $328.5^{c}$ & $326.0^{\mathrm{b}}$ & $331.0^{\mathrm{ef}}$ & $345.0^{\mathrm{k}}$ & $51.0^{\mathrm{A}}$ & $57.0^{\mathrm{D}}$ & $60.0^{\mathrm{F}}$ & $64.0^{\mathrm{H}}$ \\
\hline
\end{tabular}

${ }^{a}$ Superscript letters denote values that are significantly different $(p<0.05, \mathrm{In}=4)$. Standard deviations are reported in the Supporting Information, Table S4.

$\left(\lambda_{\max }=303 \mathrm{~nm}\right.$, Supporting Information, Figure S2) and to the theoretical value for Tyr in proteins $\left(\lambda_{\max }=305 \pm 2 \mathrm{~nm}^{22,26}\right)$. No fluorescence was detected above $350 \mathrm{~nm}$ in the difference spectra. For cPPI* solution, in the emission spectra with $\lambda_{\mathrm{ex}}=$ $275 \mathrm{~nm}$, two peaks were observed at 305 and $340 \mathrm{~nm}$, corresponding to Tyr and Trp residues in hydrophilic environment, respectively. The peak at $305 \mathrm{~nm}$ was less pronounced in the spectrum for the cPPI solution $\left(\lambda_{\text {ex }}=275\right.$ $\mathrm{nm})$. To quantify this, the ratio $(R)$ between the intensity of the difference peak (Tyr) and of the total peak (Tyr + Trp) at $305 \mathrm{~nm}$ was calculated. This ratio was 0.55 for cPPI and 0.75 for $\mathrm{CPPI}^{*}$, confirming the higher Tyr contribution in the former sample. When Tyr residues are within the Förster distance of Trp residues (9-18 $\AA$ for Tyr-to-Trp ${ }^{22}$ ) they can transfer their energy to the Trp residues, reducing the Tyr residue emission. The fact that the Tyr residue had a higher emission in the $\mathrm{CPPI}^{*}$ solution compared to the cPPI-solution may indicate that, in the unfolded protein, the amino acids are further apart than the Förster distance or that Tyr is less quenched in the $\mathrm{CPPI}^{*}$ solution.
In contrast to the pea protein solutions, we did not observe any Tyr contribution in the emission spectrum of the WPI solution. This may indicate that the Tyr signal is efficiently quenched, or energy is transferred from the Tyr residues to the Trp residues due to a distance shorter than the Förster distance. In fact, one Tyr residue is just next to $\operatorname{Trp} 19$ in the primary structure (Supporting Information). It can also be related to the high Trp/Tyr ratio in whey proteins $(0.55)$ compared to the cPPI (0.25) and iePPI (0.20) samples (Supporting Information, Table S1). The contribution of the Tyr residues increased in the WPI* solution compared to the regular WPI one $\left(R_{\mathrm{WPI}^{*}}=0.71\right)$, for the same reasons as explained for the cPPI samples, i.e., less quenching or reduced energy transfer.

It is often assumed that emission spectra recorded at 270$280 \mathrm{~nm}$ are dominated by the fluorescence of Trp residues. The current work shows that, for pea proteins, the Tyr contribution should actually not be neglected.

3.3. Front-Surface Fluorescence Spectra. To study the intrinsic fluorescence of molecules in turbid samples, such as concentrated protein solutions (above $\sim 1 \mathrm{~g} / \mathrm{L}$ ) and emulsions, 

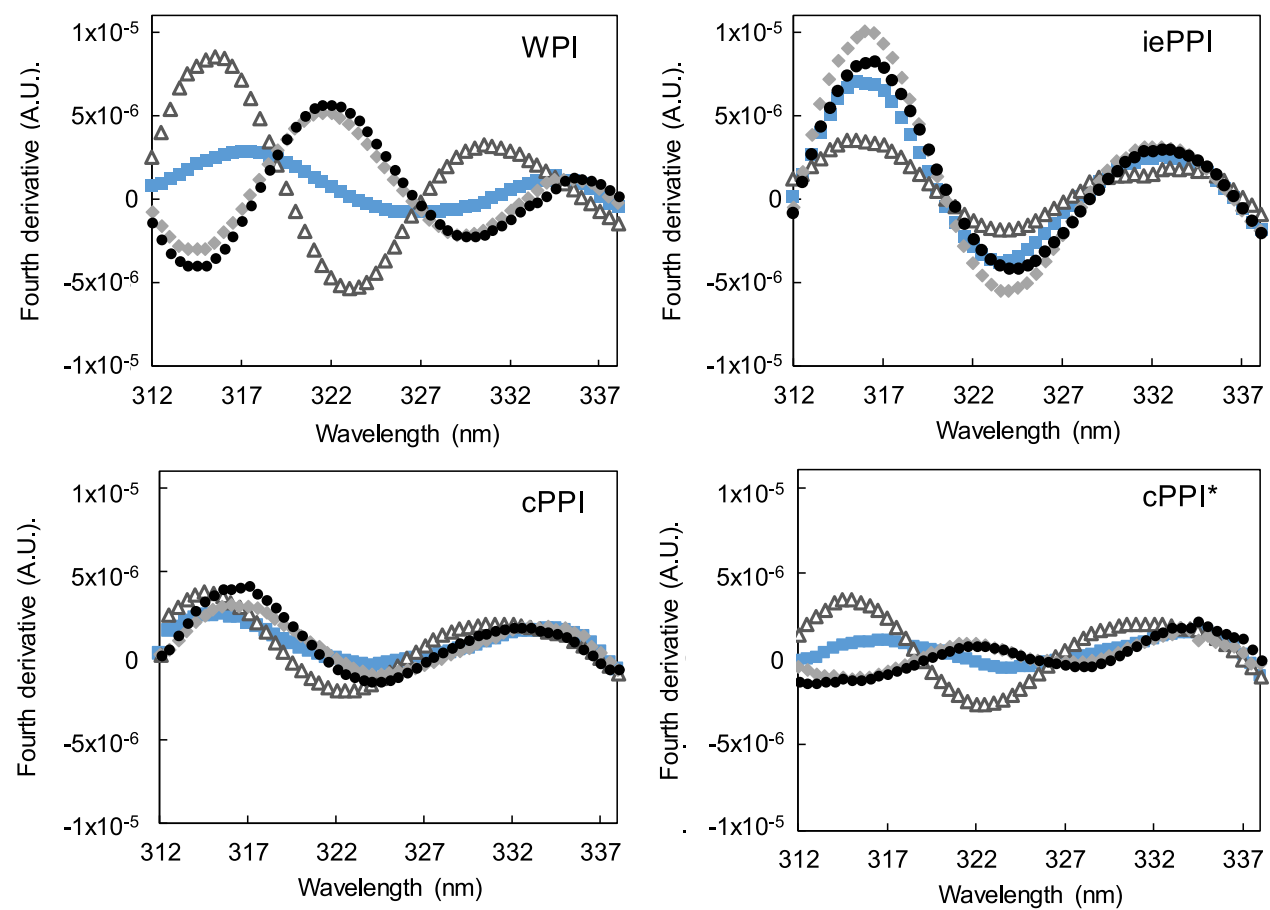

Figure 7. Fourth derivative fluorescence spectra of emulsion (solid blue square), creamed (gray triangle), and serum (solid gray diamond) phases and initial solutions (solid black sphere) of WPI, iePPI, cPPI, or cPPI* (cPPI in 6 M guanidine) containing samples recorded at $\lambda_{\text {ex }}=290 \mathrm{~nm}$. For clarity, only one representative spectrum is shown for each sample, but similar trends were obtained for dependent and independent replicates.

front-surface or front-face mode is required. The front-surface fluorescence emission spectra were normalized based on their maximum intensity, and $\lambda_{\max }$ and spectral bandwidths were compared.

3.3.1. Normalized Emission Spectra $\left(\lambda_{e x}=290 \mathrm{~nm}\right)$. Normalized front-surface emission spectra, recorded at $\lambda_{e x}=$ $290 \mathrm{~nm}$, for emulsions, creamed and serum phases, and starting solutions prepared with WPI, cPPI, iePPI, and cPPI* are reported in Figure 6.

For the WPI-based creamed phase, the $\lambda_{\max }$ was red-shifted ( $2 \mathrm{~nm}$ ) compared to the aqueous samples (solution and serum phase; Table 2), which indicates an overall slightly more hydrophilic environment of the Trp residues. The bandwidth was significantly broader $(5 \mathrm{~nm})$ compared to those for the aqueous samples, suggesting more different local environments. As expected, the bandwidth and $\lambda_{\max }$ of the WPIstabilized emulsions were in between the values of the creamed and aqueous phases, since the proteins partitioned between the oil-water interface (cream) and the water-phase (serum).

For the iePPI samples, the $\lambda_{\max }$ for the creamed phase was also red-shifted and broader compared to serum ( 8 and $4 \mathrm{~nm}$, respectively) and solution (6 and $2 \mathrm{~nm}$, respectively). This suggests that the overall environment of the Trp residues after adsorption was more hydrophilic and a greater variety of local environments. The $\lambda_{\max }$ of the serum phase was blue-shifted $(2.5 \mathrm{~nm})$ compared to the solution, and the spectrum had a smaller bandwidth $(2 \mathrm{~nm})$. The homogenization process leads to Trp residues being present in a locally more hydrophobic environment, which suggests that protein structure was affected. High pressure homogenization may induce modifications and rearrangements in the supramolecular structures of proteins. ${ }^{54,55}$ For example, a fava bean protein solution showed a red shift $(3 \mathrm{~nm})$ after high pressure homogenization, which was related to aggregate breakup. ${ }^{56}$
For the cPPI-samples, $\lambda_{\max }$ was at the same position (332 $\mathrm{nm}$ ) for the homogenized samples (i.e., emulsion, serum and cream) which shows that the Trp is in the overall same environment. However, the spectral bandwidth for the cPPI samples was significantly smaller for the solution, compared to the other samples $(2.5-3 \mathrm{~nm})$, which shows that upon homogenization the Trp residues were more spread between different environments probably due to break up of the aggregates within the homogenizer.

The spectrum for the cPPI* solution had a red-shifted $\lambda_{\max }$ $(14 \mathrm{~nm})$ and broader bandwidth $(4 \mathrm{~nm})$ compared to that for the cPPI solution, due to the more hydrophilic environment of the Trp residue after denaturation, which is in line with the results of the diluted solutions. For the $\mathrm{CPPI}^{*}$ creamed phase, $\lambda_{\max }$ was blue-shifted by $6-8 \mathrm{~nm}$ compared to the solution and serum phase, respectively, which indicates a more hydrophobic environment of the Trp residues and suggests the presence of Trp residues at the oil-water interface after adsorption at the sunflower oil-water interface.

3.3.2. Fourth Derivative Spectra $\left(\lambda_{e x}=290 \mathrm{~nm}\right)$. From the normalized emission spectra $\left(\lambda_{\mathrm{ex}}=290 \mathrm{~nm}\right.$, Figure 6), fourth derivatives were calculated to deconvolute the respective contributions of Trp residues located in hydrophobic or hydrophilic environments. ${ }^{24,25}$ Derivative spectra exhibited two maximums near 315 and $331 \mathrm{~nm}$ that are attributed to Trp residues in hydrophilic and hydrophobic environments, respectively, as previously reported for BSA (316 and 332 $\mathrm{nm}^{24}$ ) and skim milk powder (319 and $333 \mathrm{~nm}^{25}$ ).

The fourth derivative spectra of the WPI-based serum phase and solution showed a peak around $336 \mathrm{~nm}$, which is related to a hydrophilic environment (hydrophilic peak) of the Trp residues, and no peak at $\sim 315 \mathrm{~nm}$ (hydrophobic peak, Figure 7 and Table 3). The derivative spectra of the creamed phase exhibited two maximums at 315.5 and $331 \mathrm{~nm}$, respectively. 
Table 3. Wavelength (nm) of Maximum and Minimum of the Fourth Derivative and the Ratio between the Intensity of the Two Peaks $\left(I_{\max }^{332} / I_{\max }^{316}\right)^{a}$

\begin{tabular}{|c|c|c|c|c|}
\hline $\begin{array}{l}\text { fourth derivative } \\
\text { spectra }\end{array}$ & & $\begin{array}{c}\lambda_{\max } / \lambda_{\min } \\
(312-322 \mathrm{~nm})\end{array}$ & $\begin{array}{c}\lambda_{\max } \\
(317-337 \mathrm{~nm})\end{array}$ & $I_{\max }^{332} / I_{\max }^{316}$ \\
\hline \multirow[t]{4}{*}{ emulsion } & WPI & $317.5^{\mathrm{g}}$ & $334.5^{\mathrm{klmn}}$ & $0.4^{\text {qrs }}$ \\
\hline & iePPI & $316.0^{\text {cdefg }}$ & $332.0^{\text {hi }}$ & $0.4^{\mathrm{qrs}}$ \\
\hline & cPPI & $316.5^{\mathrm{fg}}$ & $333.5^{\mathrm{ijk} k \mathrm{~m}}$ & 0.vicilin \\
\hline & cPPI* & $317.0^{\mathrm{g}}$ & $334.0^{\mathrm{ijklm}}$ & $1.5^{t}$ \\
\hline \multirow[t]{4}{*}{ cream } & WPI & $315.5^{\text {bcdef }}$ & $331.0^{\mathrm{h}}$ & $0.4^{\mathrm{qr}}$ \\
\hline & iePPI & $316.0^{\text {cdefg }}$ & $332.5^{\text {hijk }}$ & $0.5^{\mathrm{qrs}}$ \\
\hline & cPPI & $315.0^{\mathrm{bcd}}$ & $331.0^{\mathrm{h}}$ & $0.6^{\mathrm{qrs}}$ \\
\hline & cPPI* & $315.0^{b c}$ & $331.0^{\mathrm{h}}$ & 0.vicilin \\
\hline \multirow[t]{4}{*}{ serum } & WPI & & $335.5^{\mathrm{mn}}$ & \\
\hline & iePPI & $316.0^{\text {cdefg }}$ & $332.5^{\text {hijk }}$ & $0.3^{q}$ \\
\hline & cPPI & $316.5^{\operatorname{defg}}$ & $334.0^{\mathrm{jklm}}$ & $0.6^{\mathrm{rs}}$ \\
\hline & cPPI* & & $334.5^{\mathrm{klmn}}$ & \\
\hline \multirow[t]{4}{*}{ solution } & WPI & & $336.5^{\mathrm{n}}$ & \\
\hline & iePPI & $316.5^{\operatorname{defg}}$ & $332.0^{\text {hij }}$ & $0.3^{\mathrm{qr}}$ \\
\hline & cPPI & $316.5^{\text {efg }}$ & $333.5^{\mathrm{ijkl}}$ & $0.5^{\mathrm{qrs}}$ \\
\hline & cPPI* & & $335.0^{\mathrm{lmn}}$ & \\
\hline
\end{tabular}

${ }^{a}$ Values presented in italics correspond to a minimum in the fourth derivative spectra. Standard deviations are reported in the Supporting Information, Table S5.

The first one can be attributed to Trp residues in hydrophobic environment, due to the adsorption of the proteins at the sunflower oil-water interface. As shown in Figure 8, all

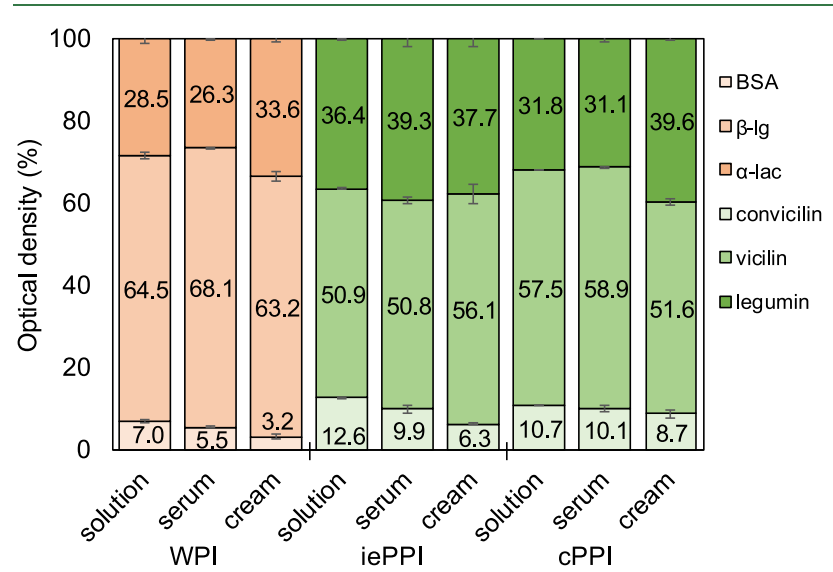

Figure 8. Protein composition measured in the solution, serum and creamed phase for WPI-, iePPI-, and cPPI- based emulsions. Colors from light to dark indicate for whey proteins (orange); BSA, $\beta$-lg, and $\alpha$-lac, and for pea proteins (green); convicilin, vicilin, and legumin. Standard deviations are reported in the Supporting Information, Table S6.

constituent proteins (BSA, $\beta$-lg, and $\alpha$-lac) adsorbed at the interface with an accumulation of $\alpha$-lactalbumin compared to the composition of the aqueous phase. It was reported that, upon adsorption, the proteins' secondary and tertiary structures change, and for $\beta$-lactoglobulin, $\operatorname{Trp}$ residues encounter a more hydrophobic environment, ${ }^{57}$ while for $\alpha$ lactalbumin a more hydrophilic environment is gained. ${ }^{58}$ In our case, the overall more hydrophobic environment of the Trp residues (Figure 7 and Table 3 ) thus suggests a strong contribution of the $\beta$-lactoglobulin residues to the total spectra. The peak near $331 \mathrm{~nm}$, attributed to Trp in the hydrophilic environment, was blue-shifted $(2 \mathrm{~nm})$ compared to the serum phase and solution, which may indicate a slightly less hydrophilic location of Trp residues in the cream. The fourth derivative spectrum of the WPI-emulsion was, as expected, in between those of the creamed and serum phases. Our results are in line with previous results obtained on BSA-stabilized sunflower $\mathrm{O} / \mathrm{W}$ emulsions ${ }^{59}$ and confirms the reproducibility of the method.

We extended this approach to pea protein-stabilized emulsions, for which, to the best of our knowledge, no fourth derivative of fluorescence spectra have been reported so far.

The fourth derivative spectra of the iePPI aqueous phases had a hydrophobic peak near $316 \mathrm{~nm}$ and a hydrophilic peak near $332 \mathrm{~nm}$. As detailed earlier, pea proteins, and plant proteins in general, have a greater molecular weight and a more complex tertiary and quaternary structure compared to dairy proteins. It is expected that the Trp residues are buried in the interior of the pea proteins' structures and hence in a relatively hydrophobic environment. The derivative spectrum for the iePPI-based creamed phase exhibited the same two peaks as the aqueous samples ( 316 and $332 \mathrm{~nm}$ ) although the relative intensity of the hydrophilic peak was higher for the creamed phase compared to the aqueous phases, 0.5 vs 0.3 (ratio $I_{\max }^{332} /$ $\left.I_{\max }^{316}\right)$,respectively, as was also concluded from the nonderivated spectra (Figure 6 and Table 2). A more hydrophilic environment of Trp after adsorption may seem counterintuitive, as adsorbed proteins are, per definition, located in close proximity to the oil phase, and this finding also opposes the result found for whey proteins. Comparison of the protein composition of the cream's interface with that of the solution indicated that there is a slight accumulation of vicilin at the interface (Figure 8), which is in line with previous research that reported higher surface activity of native vicilin compared to legumin. ${ }^{60,61}$ Our results are also in line with previous findings reported for soy protein-stabilized emulsions: the emission spectra of soy proteins adsorbed at the oil-water interface were found to be red-shifted $(4-7 \mathrm{~nm})$ compared to the emission spectra of proteins in solution. ${ }^{62}$ The Trp residues are only present in the vicilin soy protein (conglycinin) in the extension region of the $\alpha, \alpha^{\prime}$ subunit $^{62}$ and it was hypothesized that after adsorption at the oil-water interface, the Trp residues are located in a more hydrophilic environment due to protruding of the extension region in the water phase and adsorption of the core region (where no Trp is present) at the oil-water interface. ${ }^{62,63}$ The extension region of convicilin (the $\mathrm{N}$-terminal domain) is rich in Trp residues ${ }^{64}$ which is in line with the findings for soy proteins. Protruding of the convicilin extension region in the water phase thus probably explains the overall more hydrophilic environment of the Trp residues in the creamed phase of the emulsion prepared with iePPI.

The fourth derivative spectra of the cPPI sample also exhibited hydrophobic and hydrophilic peaks at $\sim 316$ and $\sim 334 \mathrm{~nm}$, respectively. The ratio between the peaks is the same for all samples (Table 3) which shows that the overall local environment of the Trp residues in cPPI did not change after protein adsorption at the oil-water interface. Legumin preferentially adsorbed at the oil-water interface (Figure 8), while, for native pea proteins, a preferential adsorption of vicilin would be expected. ${ }^{60,61}$ The so-called soluble fraction consists of nonprecipitated soluble aggregates (of various sizes and compositions) that may adsorb at the oil-water interface as aggregated protein structures, ${ }^{14}$ with Trp residues buried within the aggregates and not exposed to the oil phase. This is 


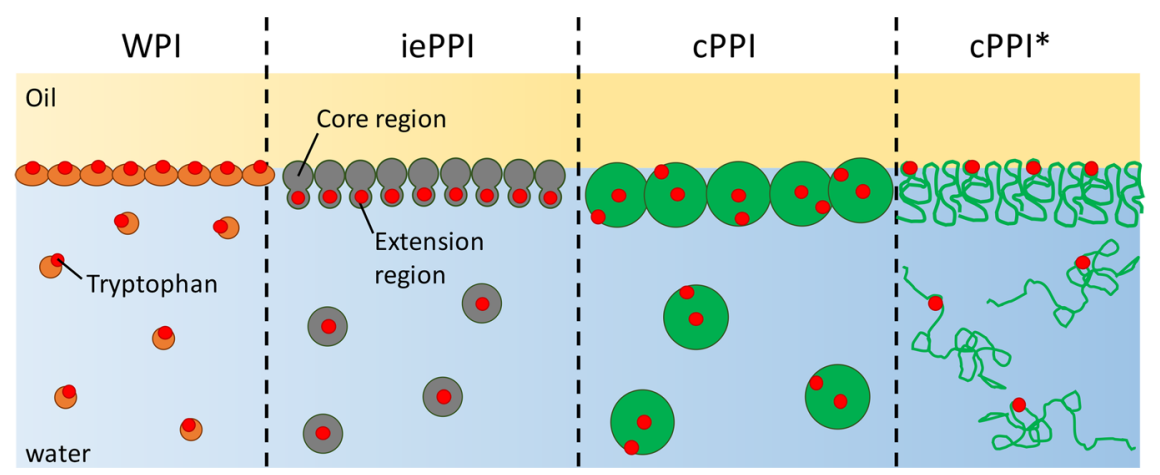

Figure 9. Schematic overview of the presumed location of Trp residues in the investigated proteins in solution and after adsorption at the oil-water interface. The illustrated molecules/structures are not to scale, and the red spheres represent the overall environment of the Trp residues.

in line with the higher surface loads and larger protein structures (Supporting Information, Table S3 and Figure S1, respectively). When dissolving $\mathrm{CPPI}$ in $6 \mathrm{M}$ guanidine hydrochloride, most of the quaternary and tertiary structures are lost and Trp residues become exposed to the aqueous environment (Figure 3). For the cPPI* solution and serum phase, the fourth derivative spectra exhibited hydrophilic peaks at 334 and $335 \mathrm{~nm}$, respectively, and no hydrophobic peak. The absence of the hydrophobic peak in the water phases (Figure 7) confirms that substantial protein unfolding occurred, as was before concluded from the red shift in the initial spectra (Figure 6 and Table 2), and from the right-angle fluorescence data in Figure 3. The creamed phase exhibited hydrophobic and hydrophilic peaks with maxima at 315 and $331 \mathrm{~nm}$, respectively. The location of the peaks is the same ( $p$ $<0.05)$ as for the WPI-stabilized creamed phase but their ratio is higher for cPPI*, suggesting a higher hydrophilic contribution. Due to complexation of guanidine hydrochloride with SDS (used for SDS-PAGE), the interfacial composition could not be quantified. For both cPPI and $\mathrm{cPPI}^{*}$ the fourth derivative spectra of the emulsions lay, as expected, between those for water phase and cream.

3.3.3. Tyrosine Contribution. The Tyr contribution to the fluorescence spectra with $\lambda_{\mathrm{ex}}=275 \mathrm{~nm}$ was determined according to the previously described procedure for the rightangle fluorescence spectra (see also the Supporting Information, Figure S3). We found a small Tyr contribution in the WPI-based samples (emulsion, creamed, and serum phases, $R$ $=0.1,0.2$, and 0.1 , respectively) and no contribution in the solution. This is in line with the right-angle fluorescence experiments (Figure 5) and confirms that the Trp residues dominate the fluorescence of whey proteins, for spectra recorded at $\lambda_{\mathrm{ex}}$ of $275 \mathrm{~nm}$. The highest ratio for the creamed phase $(R=0.2)$ suggests less quenching of Tyr after adsorption at the oil-water interface, due to conformational changes or environmental factors.

The pea protein-containing samples (iePPI, cPPI, and cPPI*) had a Tyr contribution at $305 \mathrm{~nm}$ (Supporting Information, Figure S3). For cPPI and iePPI, the Tyr contribution to the total signal was the same in the different samples, i.e., solution, serum, cream, and emulsions $(R=0.4$ and 0.5 for iePPI and cPPI samples, respectively; see also Supporting Information, Table S7). For the cPPI* samples, the Tyr contribution was the lowest in the creamed phase $(R=$ $0.5)$, and the highest in the solution $(R=0.8)$. A lower Tyr contribution may be related to increased quenching of the Tyr fluorescence signal or to increased energy transfer from Tyr to Trp due to protein conformational changes.

To wrap up, right-angle and front-surface fluorescence provide useful information about the structure of proteins in colloidal systems, from solutions to aggregate dispersions and emulsions. In contrast to WPI, the Tyr contribution to the total signal $\left(\lambda_{\mathrm{ex}}=275 \mathrm{~nm}\right)$ was not negligible for the pea protein samples and has thus to be considered in future research. Furthermore, the fourth derivative spectra provided useful insights in the structure of pea proteins; they notably confirmed that the Trp residues are buried in the hydrophobic core of pea protein structures. The commercial pea proteins are present as soluble aggregates and adsorb as such (Figure 9), accounting for no changes in the local environment of the Trp residues. For the mildly purified pea proteins, it is presumable that a Trp-free region adsorbed at the oil-water interface, and that the Trp-rich region remained in the aqueous phase. This only led to a very small shift compared to BSA that showed a $15 \mathrm{~nm}$ shift in $\lambda_{\max }$ upon adsorption. ${ }^{24}$ For pea proteins, the Tyr contribution did not change upon adsorption at the oil-water interface, which suggests that the Förster distance between the Trp and Tyr residues remained unchanged. Further research using different techniques to characterize the protein structure and the interfacial film organization, such as Fourier-transform infrared spectroscopy (FTIR) and interfacial dilatational rheology, would be useful to confirm and deepen the current findings.

\section{ASSOCIATED CONTENT}

\section{Supporting Information}

The Supporting Information is available free of charge at https://pubs.acs.org/doi/10.1021/acs.jafc.1c01005.

Amino acid residue concentrations $(\mathrm{g} / \mathrm{L}$ and $\mu \mathrm{M})$ and molar ratio Trp/Tyr or the solutions used in RA fluorescence; correlation function of the pea protein solutions; maximum intensities of RA fluorescence emission spectra normalized by protein concentration or Trp content; surface load and interfacial composition of protein stabilized emulsions; standard deviations of $\lambda_{\max }$ and bandwidth of (derivate) front surface fluorescence spectra; tyrosine contribution and ratio between the intensity of the difference peak (Tyr) and total peak (Trp+Tyr) in the front surface fluorescence emission spectra $\left(\lambda_{e x}=275 \mathrm{~nm}\right) ; \beta$-lactoglobulin sequence (PDF) 


\section{AUTHOR INFORMATION}

\section{Corresponding Author}

Claire C. Berton-Carabin - Laboratory of Food Process Engineering, 6708 WG Wageningen, The Netherlands; INRAE, UR BIA, F-44316 Nantes, France; Phone: +33240675076; Email: claire.berton-carabin@ inrae.fr

\section{Authors}

Emma B. A. Hinderink - TiFN, 6700 AN Wageningen, The Netherlands; Laboratory of Food Process Engineering, 6708 WG Wageningen, The Netherlands; ㅇo이.org/00000003-4159-9307

Karin Schroën - Laboratory of Food Process Engineering, 6708 WG Wageningen, The Netherlands

Alain Riaublanc - INRAE, UR BIA, F-44316 Nantes, France

Bérénice Houinsou-Houssou - INRAE, UR BIA, F-44316 Nantes, France

Adeline Boire - INRAE, UR BIA, F-44316 Nantes, France; (1) orcid.org/0000-0002-3515-0194

Claude Genot - INRAE, UR BIA, F-44316 Nantes, France; (1) orcid.org/0000-0002-9462-7618

Complete contact information is available at: https://pubs.acs.org/10.1021/acs.jafc.1c01005

\section{Funding}

The project was organized by and executed under the auspices of TiFN, a public - private partnership on precompetitive research in food and nutrition. The authors have declared that no competing interests exist in the writing of this publication. Funding for this research was obtained from Fromageries Bel S.A., Nutricia Research B.V., Pepsico Inc., Unilever Innovation Centre Wageningen BV., The Netherlands Organisation for Scientific Research and the Top-sector Agri\&Food NWO Project No. ALWTF. 2016.001. The Dr. ir. Aalt Dijkhuizen Fund financially supported Emma Hinderink's research stay at INRAE.

\section{Notes}

The authors declare no competing financial interest.

\section{ACKNOWLEDGMENTS}

We would like to thank Lucie Ribourg for technical assistance and Véronique Solé-Jamault for the purification of legumin and vicilin/convicilin fractions at lab scale.

\section{REFERENCES}

(1) Dickinson, E. Properties of Emulsions Stabilized with Milk Proteins: Overview of Some Recent Developments. J. Dairy Sci. 1997, 80 (10), 2607-2619.

(2) Dickinson, E. Milk Protein Interfacial Layers and the Relationship to Emulsion Stability and Rheology. Colloids Surf., B 2001, 20, 197-210.

(3) McClements, D. J. Emulsion Stability. Food Emulsions Principles, Practices, and Techniques 2004, 1-71.

(4) Dickinson, E.; Matsumura, Y. Time-Dependent Polymerization of b-Lactoglobulin through Disulphide Bonds at the Oil-Water Interface in Emulsions. Int. J. Biol. Macromol. 1991, 13 (1), 26-30.

(5) Monahan, F. J.; McClements, D. J.; Kinsella, J. E. Polymerization of Whey Proteins in Whey Protein-Stabilized Emulsions. J. Agric. Food Chem. 1993, 41, 1826-1829.

(6) Hinderink, E. B. A.; Sagis, L.; Schroën, K.; Berton-Carabin, C. C. Behavior of Plant-Dairy Protein Blends at Air-Water and Oil-Water Interfaces. Colloids Surf., B 2020, 192, 111015.
(7) Murray, B. S. Rheological Properties of Protein Films. Curr. Opin. Colloid Interface Sci. 2011, 16 (1), 27-35.

(8) Dickinson, E.; Murray, B. S.; Stainsby, G. Coalescence Stability of Emulsion-Sized Droplets at a Planar Oil-Water Interface and the Relationship to Protein Film Surface Rheology. J. Chem. Soc., Faraday Trans. 1 1988, 84 (3), 871.

(9) Gumus, C. E.; Decker, E. A.; McClements, D. J. Formation and Stability of $\omega-3$ Oil Emulsion-Based Delivery Systems Using Plant Proteins as Emulsifiers: Lentil, Pea, and Faba Bean Proteins. Food Biophys. 2017, 12, 186

(10) Ladjal Ettoumi, Y.; Berton-Carabin, C. C.; Chibane, M.; Schroën, K. Legume Protein Isolates for Stable Acidic Emulsions Prepared by Premix Membrane Emulsification. Food Biophys. 2017, 12 (1), 119-128.

(11) Yerramilli, M.; Longmore, N.; Ghosh, S. Improved Stabilization of Nanoemulsions by Partial Replacement of Sodium Caseinate with Pea Protein Isolate. Food Hydrocolloids 2017, 64, 99-111.

(12) Ho, K. K.H.Y.; Schroen, K.; San Martin-Gonzalez, M. F.; Berton-Carabin, C. C. Physicochemical Stability of Lycopene-Loaded Emulsions Stabilized by Plant or Dairy Proteins. Food Struct. 2017, 12, $34-42$.

(13) Roy, F.; Boye, J. I.; Simpson, B. K. Bioactive Proteins and Peptides in Pulse Crops: Pea, Chickpea and Lentil. Food Res. Int. 2010, 43 (2), 432-442.

(14) Hinderink, E. B. A.; Kaade, W.; Sagis, L.; Schroën, K.; BertonCarabin, C. C. Microfluidic Investigation of the Coalescence Susceptibility of Pea Protein-Stabilised Emulsions : Effect of Protein Oxidation Level. Food Hydrocolloids 2020, 102 (102), 105610.

(15) Estrada, P. D.; Berton-Carabin, C. C.; Schlangen, M.; Haagsma, A.; Pierucci, A. P. T. R.; van der Goot, A. J. Protein Oxidation in Plant Protein-Based Fibrous Products: Effects of Encapsulated Iron and Process Conditions. J. Agric. Food Chem. 2018, 66 (42), 1110511112.

(16) Gumus, C. E.; Decker, E. A.; McClements, D. J. Impact of Legume Protein Type and Location on Lipid Oxidation in Fish Oil-inWater Emulsions: Lentil, Pea, and Faba Bean Proteins. Food Res. Int. 2017, 100, 175-185.

(17) McCarthy, N. A.; Kennedy, D.; Hogan, S. A.; Kelly, P. M.; Thapa, K.; Murphy, K. M.; Fenelon, M. A. Emulsification Properties of Pea Protein Isolate Using Homogenization, Microfluidization and Ultrasonication. Food Res. Int. 2016, 89, 415-421.

(18) Geerts, M. E. J.; Nikiforidis, C. V.; van der Goot, A. J.; van der Padt, A. Protein Nativity Explains Emulsifying Properties of Aqueous Extracted Protein Components from Yellow Pea. Food Struct. 2017, 14 (May), 104-111.

(19) Sridharan, S.; Meinders, M. B. J.; Bitter, J. H.; Nikiforidis, C. V. Pea Flour as Stabilizer of Oil-in-Water Emulsions: Protein Purification Unnecessary. Food Hydrocolloids 2020, 101, 105533.

(20) Kornet, C.; Venema, P.; Nijsse, J.; van der Linden, E.; van der Goot, A. J.; Meinders, M. Yellow Pea Aqueous Fractionation Increases the Specific Volume Fraction and Viscosity of Its Dispersions. Food Hydrocolloids 2020, 99, 105332.

(21) Genot, C.; Montenay-Garestier, T.; Drapron, R. Intrinsic Spectrofluorometry Applied to Soft Wheat (Triticum Aestivum) Flour and Gluten to Study Lipid-Protein Interactions. LWT - Food Sci. Technol. 1984, 17 (3), 129-133.

(22) Lakowicz, J. R. Principles of Fluorescence Spectroscopy 2007, 341.

(23) Rampon, V.; Genot, C.; Riaublanc, A.; Anton, M.; Axelos, M. A. V.; McClements, D. J. Front-Face Fluorescence Spectroscopy Study of Globular Proteins in Emulsions: Displacement of BSA by a Nonionic Surfactant. J. Agric. Food Chem. 2003, 51 (9), 2482-2489.

(24) Rampon, V.; Lethuaut, L.; Mouhous-Riou, N.; Genot, C. Interface Characterization and Aging of Bovine Serum Albumin Stabilized Oil-in-Water Emulsions as Revealed by Front-Surface Fluorescence. J. Agric. Food Chem. 2001, 49 (8), 4046-4051.

(25) Granger, C.; Barey, P.; Toutain, J.; Cansell, M. Direct Quantification of Protein Partitioning in Oil-in-Water Emulsion by Front-Face Fluorescence: Avoiding the Need for Centrifugation. Colloids Surf., B 2005, 43 (3-4), 158-162. 
(26) Casterlain, C.; Genot, C. Conformational Changes of Bovine Serum Albumin upon Its Adsorption in Dodecane-in-Water Emulsions as Revealed by Front-Face Steady-State Fluorescence. Biochim. Biophys. Acta, Gen. Subj. 1994, 1199, 59-64.

(27) Shewry, P. R.; Napier, J. A.; Tatham, A. S. Seed Storage Proteins: Structures and Biosynthesis. Plant Cell 1995, 7 (7), 945956.

(28) Berton, C.; Genot, C.; Ropers, M. H. Quantification of Unadsorbed Protein and Surfactant Emulsifiers in Oil-in-Water Emulsions. J. Colloid Interface Sci. 2011, 354 (2), 739-748.

(29) Gueguen, J.; Vu, A. T.; Schaeffer, F. Large-scale Purification and Characterisation of Pea Globulins. J. Sci. Food Agric. 1984, 35 (9), $1024-1033$.

(30) Amagliani, L.; O’Regan, J.; Kelly, A. L.; O’Mahony, J. A. Composition and Protein Profile Analysis of Rice Protein Ingredients.

J. Food Compos. Anal. 2017, 59, 18-26.

(31) Gorissen, S. H. M.; Crombag, J. J. R.; Senden, J. M. G.; Waterval, W. A. H.; Bierau, J.; Verdijk, L. B.; van Loon, L. J. C. Protein Content and Amino Acid Composition of Commercially Available Plant-Based Protein Isolates. Amino Acids 2018, 50 (12), $1685-1695$.

(32) Smith, P. K.; Krohn, R. I.; Hermanson, G. T.; Mallia, A. K.; Gartner, F. H.; Provenzano, M. D.; Fujimoto, E. K.; Goeke, N. M.; Olson, B. J.; Klenk, D. C. Measurement of Protein Using Bicinchoninic Acid. Anal. Biochem. 1985, 150 (1), 76-85.

(33) Mason, P. E.; Neilson, G. W.; Dempsey, C. E.; Barnes, A. C.; Cruickshank, J. M. The Hydration Structure of Guanidinium and Thiocyanate Ions: Implications for Protein Stability in Aqueous Solution. Proc. Natl. Acad. Sci. U. S. A. 2003, 100 (8), 4557-4561.

(34) Barac, M.; Cabrilo, S.; Pesic, M.; Stanojevic, S.; Zilic, S.; Macej, O.; Ristic, N. Profile and Functional Properties of Seed Proteins from Six Pea (Pisum Sativum) Genotypes. Int. J. Mol. Sci. 2010, 11 (12), 4973-4990.

(35) Gatehouse, J. A.; Lycett, G. W.; Croy, R. R. D.; Boulter, D. The Post-Translational Proteolysis of the Subunits of Vicilin from Pea (Pisum Sativum L.). Biochem. J. 1982, 207 (3), 629-632.

(36) Taniguchi, M.; Lindsey, J. S. Database of Absorption and Fluorescence Spectra of $>300$ Common Compounds for Use in PhotochemCAD. Photochem. Photobiol. 2018, 94 (2), 290-327.

(37) Taniguchi, M.; Du, H.; Lindsey, J. S. PhotochemCAD 3: Diverse Modules for Photophysical Calculations with Multiple Spectral Databases. Photochem. Photobiol. 2018, 94 (2), 277-289.

(38) Layne, E. Spectrophotometric and Turbidimetric Methods for Measuring Proteins. Methods Enzymol. 1957, 3 (C), 447-454.

(39) Oreskes, I.; Mandel, D. Spectrophotometric Assay with Turbidity Correction of Sized Immunoglobulin G Aggregates. Anal. Biochem. 1979, 99 (2), 346-351.

(40) Gueguen, J; Chevalier, M; And, J B.; Schaeffer, F Dissociation and Aggregation of Pea Legumin Induced by PH and Ionic Strength. J. Sci. Food Agric. 1988, 44 (2), 167-182.

(41) van der Goot, A. J.; Pelgrom, P. J. M.; Berghout, J. A. M.; Geerts, M. E. J.; Jankowiak, L.; Hardt, N. A.; Keijer, J.; Schutyser, M. A. I.; Nikiforidis, C. V.; Boom, R. M. Concepts for Further Sustainable Production of Foods. J. Food Eng. 2016, 168, 42-51.

(42) Vivian, J. T.; Callis, P. R. Mechanisms of Tryptophan Fluorescence Shifts in Proteins. Biophys. J. 2001, 80 (5), 2093-2109.

(43) Burstein, E. A.; Vedenkina, N. S.; Ivkova, M. N. Fluorescence and the Location of Trp Residues in Protein Molecules. Photochem. Photobiol. 1973, 18, 263-279.

(44) Xiang, B. Y.; Ngadi, M. O.; Ochoa-Martinez, L. A.; Simpson, M. V. Pulsed Electric Field-Induced Structural Modification of Whey Protein Isolate. Food Bioprocess Technol. 2011, 4 (8), 1341-1348.

(45) Gatehouse, J. A.; Croy, R. R. D.; Boulter, D.; Shewry, P. R. The Synthesis and Structure of Pea Storage Proteins. Crit. Rev. Plant Sci. 1984, 1 (4), 287-314.

(46) Croy, R. R.; Gatehouse, J. A.; Tyler, M.; Boulter, D. The Purification and Characterization of a Third Storage Protein (Convicilin) from the Seeds of Pea (Pisum Sativum L.). Biochem. J. 1980, 191 (2), 509-516.
(47) Meagher, J. L.; Beechem, J. M.; Olson, S. T.; Gettins, P. G.W. Deconvolution of the Fluorescence Emission Spectrum of Human Antithrombin and Identification of the Tryptophan Residues That Are Responsive to Heparin Binding. J. Biol. Chem. 1998, 273 (36), 23283-23289.

(48) PAJOT, P. Fluorescence of Proteins in 6-M Guanidine Hydrochloride. Eur. J. Biochem. 1976, 63, 263-269.

(49) Rawel, H. M.; Czajka, D.; Rohn, S.; Kroll, J. Interactions of Different Phenolic Acids and Flavonoids with Soy Proteins. Int. J. Biol. Macromol. 2002, 30 (3-4), 137-150.

(50) Estévez, M.; Kylli, P.; Puolanne, E.; Kivikari, R.; Heinonen, M. Fluorescence Spectroscopy as a Novel Approach for the Assessment of Myofibrillar Protein Oxidation in Oil-in-Water Emulsions. Meat Sci. 2008, 80 (4), 1290-1296.

(51) Hellwig, M. Analysis of Protein Oxidation in Food and Feed Products. J. Agric. Food Chem. 2020, 68, 12870.

(52) Qin, B. Y.; Bewley, M. C.; Creamer, L. K.; Baker, H. M.; Baker, E. N.; Jameson, G. B. Structural Basis of the Tanford Transition of Bovine $\beta$-Lactoglobulin. Biochemistry 1998, 37 (40), 14014-14023.

(53) Uhrínová, S.; Smith, M. H.; Jameson, G. B.; Uhrín, D.; Sawyer, L.; Barlow, P. N. Structural Changes Accompanying PH-Induced Dissociation of the $\beta$ - Lactoglobulin Dimer. Biochemistry 2000, 39 (13), 3565-3574.

(54) Keerati-U-Rai, M.; Corredig, M. Effect of Dynamic High Pressure Homogenization on the Aggregation State of Soy Protein. J. Agric. Food Chem. 2009, 57 (9), 3556-3562.

(55) Rampon, V.; Riaublanc, A.; Anton, M.; Genot, C.; McClements, D. J. J. Agric. Food Chem. 2003, 51, 5900-5905.

(56) Yang, J.; Liu, G.; Zeng, H.; Chen, L. Effects of High Pressure Homogenization on Faba Bean Protein Aggregation in Relation to Solubility and Interfacial Properties. Food Hydrocolloids 2018, 83 (May), 275-286.

(57) Sakuno, M. M.; Matsumoto, S.; Kawai, S.; Taihei, K.; Matsumura, Y. Langmuir 2008, 24, 11483-11488.

(58) Zhai, J.; Hoffmann, S. V.; Day, L.; Lee, T.; Augustin, M. A.; Aguilar, M.; Wooster, T. J. Langmuir 2012, 28, 2357.

(59) Rampon, V.; Brossard, C.; Mouhous-Riou, N.; Bousseau, B.; Llamas, G.; Genot, C. The Nature of the Apolar Phase Influences the Structure of the Protein Emulsifier in Oil-in-Water Emulsions Stabilized by Bovine Serum Albumin. A Front-Surface Fluorescence Study. Adv. Colloid Interface Sci. 2004, 108-109, 87-94.

(60) Dagorn-Scaviner, C.; Gueguen, J.; Lefebvre, J. A Comparison of Interfacial Behaviours of Pea (Pisum Sativum L.) Legumin and Vicilin at Air/Water Interface. Nahrung 1986, 30 (3-4), 337-347.

(61) Dagorn-Scavinier, C.; Gueguen, J.; Lefebvre, J. Emulsifying Properties of Pea Globulins as Related to Their Adsorption Behaviors. J. Food Sci. 1987, 52 (2), 335-341.

(62) Miriani, M.; Keerati-U-Rai, M.; Corredig, M.; Iametti, S.; Bonomi, F. Denaturation of Soy Proteins in Solution and at the OilWater Interface : A Fluorescence Study. Food Hydrocolloids 2011, 25 (4), 620-626.

(63) Keerati-u-rai, M.; Miriani, M.; Iametti, S.; Bonomi, F.; Corredig, M. Structural Changes of Soy Proteins at the Oil-Water Interface Studied by Fluorescence Spectroscopy. Colloids Surf., B 2012, 93, 41-48.

(64) Sáenz De Miera, L. E.; Ramos, J.; Pérez De La Vega, M. A Comparative Study of Convicilin Storage Protein Gene Sequences in Species of the Tribe Vicieae. Genome 2008, 51 (7), 511-523. 